\title{
Demonstration of Mycoplasma capricolum subsp. capripneumoniae and Mycoplasma mycoides subsp. mycoides, Small Colony type in Outbreaks of Caprine Pleuropneumonia in Eastern Tanzania
}

\author{
By L.J.M. Kusiluka ${ }^{1,3}$,W. D. Semuguruka ${ }^{2}$, R.R. Kazwala ${ }^{3}$, B. Ojeniy ${ }^{l}$ and N.F. Friis ${ }^{4}$
}

${ }^{1}$ Department of Veterinary Microbiology, The Royal Veterinary and Agricultural University Frederiksberg, Denmark, ${ }^{2}$ Departments of Veterinary Pathology \& ${ }^{3}$ Veterinary Medicine and Public Health, Sokoine University of Agriculture, Morogoro, Tanzania and ${ }^{4}$ Danish Veterinary Laboratory, Copenhagen, Denmark.

\begin{abstract}
Kusiluka LJM, Semuguruka WD, Kazwala RR, Ojeniyi B, Friis NF: Demonstration of Mycoplasma capricolum subsp. capripneumoniae and Mycoplasma mycoides subsp. mycoides, Small Colony type in outbreaks of caprine pleuropneumonia in eastern Tanzania. Acta vet. scand. 2000, 41, 311-319 - An outbreak of caprine pleuropneumonia involving about 1200 goats in the Coast and Morogoro regions of eastern Tanzania is reported. The major clinical findings were severe respiratory distress, fever, mucopurulent nasal discharge and high mortality involving all age groups and both sexes of goats. The morbidity and mortality rates were $45 \%-90 \%$ and $14 \%$ $50 \%$, respectively. The principal pathological lesions were confined to the thoracic cavity and comprised hydrothorax and serofibrinous pleuropneumonia. The histopathological features consisted of a necrotizing fibrinous pleuropneumonia characterized by different degrees of vasculitis, and fibrinocellular exudation into the alveolar septae and lumina, and into interlobular septae and pleura. Mycoplasma capricolum subsp. capripneumoniae, Mycoplasma mycoides subsp. mycoides, Small Colony type Mycoplasma ovipneumoniae and Mycoplasma arginini were isolated from some of the examined goats including a case with a sequestrum which yielded Mycoplasma mycoides subsp. mycoides, Small Colony type. This work reports the first description of an outbreak of caprine pleuropneumonia in Tanzania in which M. capripneumoniae and M. mycoides subsp. mycoides, Small Colony type were concurrently isolated.
\end{abstract}

goat.

\section{Introduction}

Mycoplasmosis is a serious problem which adversely affect the productivity of the goat industry worldwide (Lefèvre et al. 1987, DaMassa et al. 1992, Thiaucourt \& Bölske 1996). The major diseases include contagious caprine pleuropneumonia (CCPP) which is caused by $M$. capricolum subsp. capripneumoniae (M. capripneumoniae) (MacOwan \& Minette 1976, Bölske 1995, Thiaucourt \& Bölske 1996). M. mycoides subsp. mycoides, Large Colony type (M. mycoides LC), M. mycoides subsp. capri (M. capri), M. capricolum subsp. capricolum (M. capricolum), M. agalactiae and M. putrefaciens, singly or together may cause the mastitis, arthritis, keratitis, pneumonia and septicaemia (MAKePS) syndrome in single or in groups of animals within a herd (Rodriguez et al. 1995, Thiaucourt \& Bölske 1996). M. ovipneumoniae 
participates in the causation of acute or chronic pneumonia (Jones \& Wood 1988, Rosendal 1994) while $M$. conjunctivae causes caprine keratoconjunctivitis (Radwan et al. 1985, DaMassa et al. 1992). M. arginini is frequently isolated from normal and pneumonic goat lungs although its pathogenic potential has not been well defined (Rosendal 1994).

CCPP is one of the most serious infectious diseases of goats with very high morbidity and heavy mortalities in newly infected animals (McMartin et al. 1980). The disease is prevalent in Africa where $M$. capripneumoniae has been isolated in Chad, Eritrea, Ethiopia, Kenya, Niger, Sudan, Tunisia and Uganda, and in Asia where $M$. capripneumoniae has been isolated in Nepal, Oman, United Arab Emirates, Turkey and Yemen (MacOwan \& Minette 1976, 1977, Thiaucourt \& Bölske 1996, Nicholas 1999). Although the presence of CCPP has been suspected in Tanzanian goats since the early 1980s (Nyange \& Mbise 1983, Msami 1991) it was only confirmed in 1998 (Msami et al. 1998). During this period the disease was confirmed in Arusha, Dar es Salaam, Kilimanjaro and Tanga regions but its origin could not be traced. Thereafter, there were increasing numbers of reports of CCPP-suspected outbreaks in the Coast, Dodoma, Iringa, Morogoro, Singida and Mtwara regions which, however, could not be substantiated by laboratory confirmation. The present work describes an outbreak of caprine pleuropneumonia in the Coast and Morogoro regions of eastern Tanzania in which both $M$. capripneumoniae and $M$. mycoides subsp. mycoides, Small Colony type (M. mycoides SC) were isolated.

\section{Materials and methods}

\section{History}

An outbreak of a highly contagious disease was noticed in a goat unit at the Sokoine University of Agriculture (SUA) Teaching and Research
Farm, Morogoro, Tanzania towards the end of April 1999. The affected herd comprised about 263 Small East African goats. Signs of the disease started to occur after introduction of goats purchased from local animal markets. About one week later clinical cases and deaths were also noticed in 2 other goat units of the same farm which consisted of 420 and 150 goats, respectively. Around the same time outbreaks of a highly contagious disease with high mortality were being observed in some herds in the periurban areas of Morogoro municipality. One of these herds comprising about 200 goats had introduced animals from Gairo division which is one of the main goat keeping areas in Morogoro region, located about $100 \mathrm{~km}$ west of Morogoro municipality on the border with Mpwapwa district of Dodoma region. Goat keepers in Morogoro region usually purchase goats from Dodoma or Singida regions and the animals are transported via Gairo to other locations within Morogoro region or other parts of the country. About 3 months before the outbreaks in Morogoro, there were reports of massive deaths among goats in Mpwapwa district caused by a highly contagious respiratory disease.

In July 1999, an outbreak of a highly contagious respiratory disease of goats occurred in Mkuranga area, in the Coast region located about $200 \mathrm{~km}$ east of Morogoro municipality. In one herd, 50 of the 70 goats were diseased and 20 of them died. In November 1999, an outbreak of a similar diseased occurred in Chalinze area, also in the Coast region about midway between Morogoro and Mkuranga. In a herd where epidemiological information was gathered, 9 out of 12 goats were affected and 6 of them died.

\section{Clinical and pathological examination}

A thorough clinical examination was carried out on CCPP-suspected goats at SUA farm and in one herd in the peri-urban area of Morogoro 

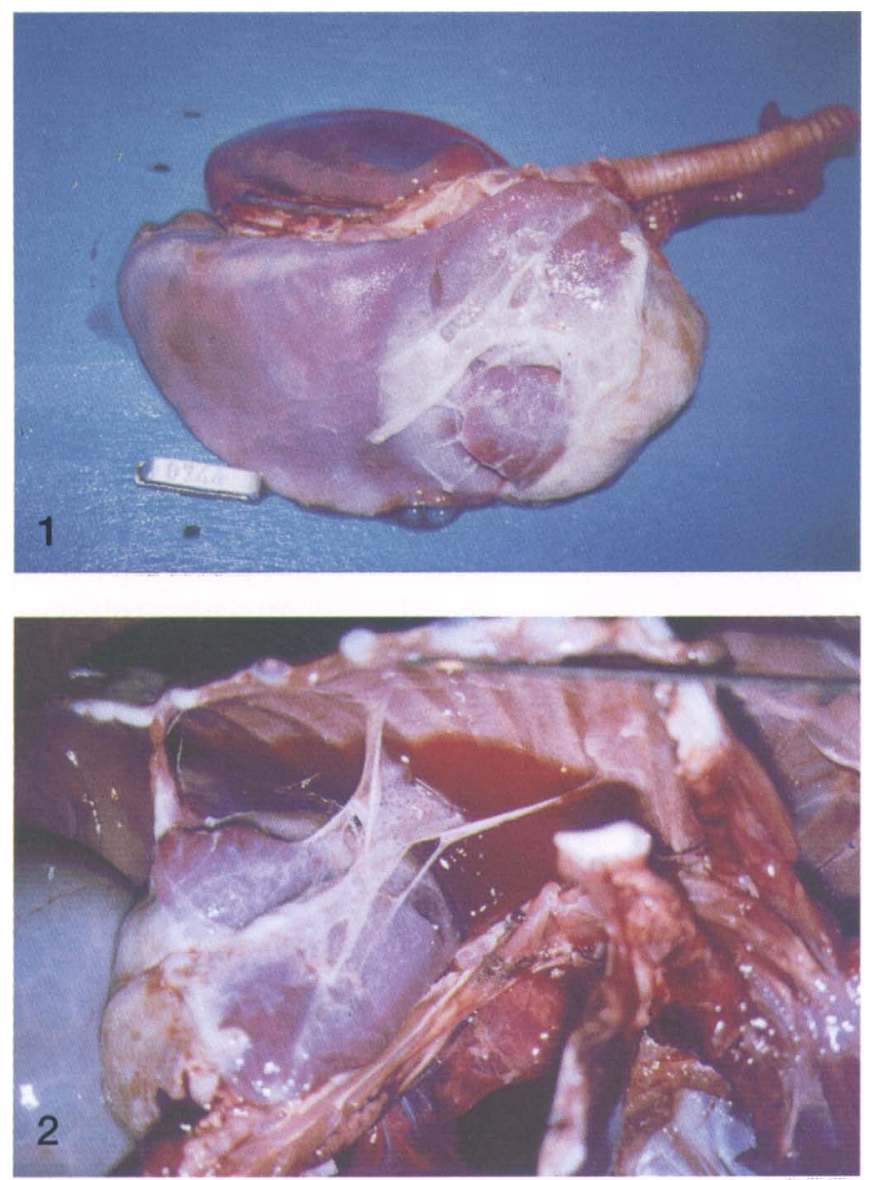

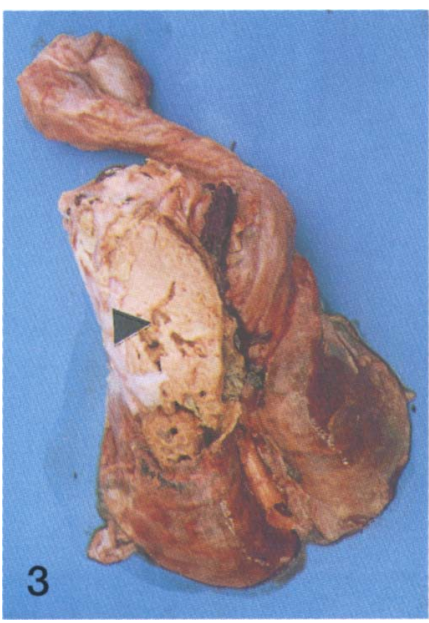

Figure 1. Fibrinous covering over the lung of a goat with pleuropneumonia.

Figure 2. Thoracic cavity of a goat with pleuropneumonia showing fibrinous adhesions between the lungs and the thoracic wall and hydrothorax.

Figure 3 . A section of a sequestrum from a goat with pleuropneumonia showing brownish to yellow amorphous necrotic material enclosed in a fibrous capsule (arrow). M. mycoides SC was isolated from the lesion. municipality. Anamnestic and clinical data were also collected in the visited herds in the Mkuranga and Chalinze outbreaks. A detailed pathological examination of 66 goat carcasses from SUA farm was carried out. In addition, 13 other CCPP-suspected lungs in the same farm and 5 lungs from other goat herds in Morogoro municipality were also examined for their macroscopic pathology as were also 6 lungs from Gairo area and 2 from Kilosa district, both in Morogoro region. One goat from Mkuranga and another from Chalinze were also necropsied. A histopathological examination of 16 lungs from SUA farm and those from Mkuranga and Chalinze was performed.

\section{Microbiological examination}

Respiratory tract specimens from goats examined at SUA farm and other locations in Morogoro region as well as those from Mkuranga and Chalinze were submitted for mycoplasmological examination at the Faculty of Veterinary Medicine, Sokoine University of Agriculture. Details of mycoplasma isolation and identification procedures are described elsewhere (Kusiluka et al. 2000). 


\section{Results}

Clinical signs

All age groups and both sexes of goats were affected. Initially, they appeared depressed, were reluctant to move and lagged behind the group. This was followed by respiratory distress that was aggravated by exercise. Tachypnoea and dyspnoea were evident and often accompanied by excessive mucopurulent nasal discharge which in some cases blocked the nostrils. Grunting, protrusion of the tongue and drooling of saliva were observed in acute cases, which were also pyrexic $\left(40-41^{\circ} \mathrm{C}\right)$. Acutely affected animals breathed with their necks and heads extended and, stood with the limbs abducted or terminally became recumbent. Subacute and chronic cases exhibited milder symptoms with intermittent coughing being observed mainly following exertion.

At SUA farm, the morbidity was $45 \%$ and mortality was $14 \%(n=833)$ and in one herd in Morogoro municipality $(\mathrm{n}=200)$ the morbidity and mortality were $90 \%$ and $50 \%$, respectively. In the Mkuranga herd $(\mathrm{n}=70)$, the morbidity was $71.4 \%$ and mortality was $28.6 \%$, whereas in the Chalinze herd $(\mathrm{n}=12)$, the morbidity and mortality were $75 \%$ and $50 \%$, respectively.

Following the suspicion of CCPP at SUA farm, the affected goats were treated with oxytetracyline, tylosin or penicillin-dihydrostreptomycin but recurrence of clinical signs was often noticed. In the Mkuranga herd, mass treatment with oxytetracycline curtailed further deaths.

\section{Pathological features}

In the necropsied goats at SUA farm, the major pathological changes were confined to the thoracic cavity. In the majority of cases there was hydrothorax with a yellowish turbid fluid containing flecky material. Fibrinous pleuropneumonia was observed in 53 out of the 66 goats necropsied. Of these 53 goats, 42 had severe fribrinous pneumonia with pleurisy, and 34 of the 42 goats had thick deposits of fibrin on the pericardial sac and variable degrees of pericarditis and hydropericardium. Of the 34 carcasses, 30 also had hydropericardium with fibrinous flecks in the fluid.

The diaphragmatic lobes of the lungs were most frequently affected with dark red or purple consolidation involving a greater part or the entire lobes. Fibrinous adhesions between the caudal and cardiac lobes was a common feature. The left or right side of the cardiac and apical cranial lobes were at times also involved with smaller dark red or purple foci. A thick fibrinous layer covering the lung pleura was a common feature (Fig. 1). Fibrinous adhesions between the lungs and the costal pleura were also observed (Fig. 2). In one case, the left cranial lobe and the adjacent part of the caudal lobe had dark brownish to yellow amorphous material enclosed in a thick fibrous capsule that resembled a sequestrum like those observed in cattle with chronic CBPP (Fig. 3). In all cases of severe lung affection there were adhesions between the lungs and the pericardium. The cut surface of the affected lungs was either moist or dry with granular dark-red, dirty white or yellowish brown areas giving a mottled appearance. The above features were also seen in the lungs from Morogoro municipality, Gairo and Kilosa.

The gross lesions of the necropsied goat at Mkuranga were similar to those of SUA farm. The thoracic cavity contained about 1 litre of yellowish fluid. Both lungs were consolidated and the mediastinal and bronchial lymph nodes were enlarged. The Chalinze case had a unilateral affection manifested by consolidation of the diaphragmatic, accessory and posterior portions of the apical lobes. Adhesions between the diaphragmatic lobes and the pleural were evident.

Histopathologically, early microscopic changes consisted of diffuse intense, hyperaemia and 
necrotising fibrinous pleuropneumonia, characterized by different degrees of vasculitis. Fibrinocellular exudation in alveolar septae and alveolar lumina, bronchioles as well as interlobular septae and pleura was evident, and especially prominent in 7 cases at SUA farm. The inflammatory cellular exudates consisted of neutrophils and mononuclear cells. Hyperplasia of the epithelial lining of the terminal and respiratory bronchioles was also evident. In late lesions, the fibrinous and cellular exudation remained prominent with focal and later, diffuse necrosis as well as destruction of the lung tissue architecture.

\section{Microbiological examination}

Detailed results of mycoplasma isolation among CCPP-suspected goats in Tanzania, including the Coast and Morogoro regions have been described in a separate paper dealing with general mycoplasma isolation (Kusiluka et al. 2000). However, for completion purposes, data on mycoplasma isolation from 23 lungs including 18 which were subjected to histopathology (16 from SUA, 1 from Mkuranga and 1 from Chalinze) and 5 lungs from Morogoro municipality is included. Among the 16 lungs from SUA goats, 12 yielded mycoplasmas comprising $M$. capripneumoniae (5), M. ovipneumoniae (6) and $M$. mycoides SC (1). The remaining lungs did not yield mycoplasmas and were submitted to the Department of Veterinary Microbiology and Parasitology, SUA for bacteriological examination. Pasteurella haemolytica was isolated from all of them and 1 also yielded Pasteurella multocida. Among the 7 lungs which exhibited distension of the interlobular septa at histopathology, 3 of them yielded a $M$. capripneumoniae and $M$. ovipneumoniae mixed flora, 2 yielded $M$. capripneumoniae only, 1 yielded $M$. ovipneumoniae only and another lung (with sequestrum) yielded $M$. mycoides SC.
Three goat lungs from Morogoro municipality yielded $M$. mycoides SC. M. capripneumoniae was isolated from the 2 lungs from Mkuranga and Chalinze, and a pleural fluid sample accompanying the lung from Mkuranga had a mixed $M$. capripneumoniae, M. mycoides SC and $M$. ovipneumoniae infection.

\section{Discussion}

The clinical and pathological features observed in this study were highly suggestive of caprine mycoplasmal pleuropneumonia including CCPP. Although most features in the present outbreaks resembled those described previously by other workers (Bölske et al. 1995), other features which are considered not typical of CCPP such as distension of the interlobular septae and hydropericardium (Hutcheon 1881 cited by McMartin et al. 1980, Thiaucourt et al. 1996) were also evident, even cases where $M$. capripneumoniae alone was isolated. Thus, it appears that distension of both the intralobular and interlobular septae does occur in CCPP. MacOwan \& Minette (1976) reported enlargement of interlobular septa in 2 goats experimentally infected with Mycoplasma strain F38 which was isolated from a CCPP case in Kenya. The 2 cases had other lesions that were indistinguishable from field cases of CCPP or goats infected through contact transmission. Kaliner \& MacOwan (1976) also reported the presence of distension of interlobular septa in some of experimental contact goats infected with strain G69, a Kenyan isolate of $M$. capripneumoniae as well as those infected with strain F30 of the $M$. mycoides group. The distension of interlobular septae is attributed to fibrinocellular exudation which occurs both in M. capripneumoniae and M. mycoides subsp. mycoides infections (Kaliner \& MacOwan 1976, Ojo 1976, Msami et al. 1998) and was also observed in the present study. However, distension of interlobular septa may not occur in goats experimen- 
tally infected with $M$. mycoides LC (Bölske et al. 1989).

Fibrinous pericarditis and hydropericardium have not been described as prominent features in $M$. capripneumoniae infection but they have been observed in $M$. mycoides subsp. mycoides infection in goats (Ojo 1976, Bar-Moshe \& Rappaport 1981, Rodríguez et al. 1995) and in sheep (Okoh \& Ocholi 1986). In the present study, the 2 features were encountered in the majority of goats with severe fibrinous pleuropneumonia including cases from which either $M$. capripneumoniae or $M$. mycoides SC were isolated. Occurrence of fibrinous pericarditis in experimental contact CCPP cases has been reported previously (Kaliner \& MacOwan 1976, MacOwan \& Minette 1976). Exudative pericarditis is also observed in contagious bovine pleuropneumonia (Masiga et al. 1996).

It should be noted, however, that in the outbreaks described here both $M$. capripneumoniae and $M$. mycoides SC were involved and were isolated from indistinguishable pathological lesions, including one case in which both mycoplasmas were isolated. Obviously, under such circumstances it is difficult to ascribe the observed lesions to any one of the 2 mycoplasma species. On the contrary, in previous descriptions of CCPP and other mycoplasmal pleuropneumonias either $M$. capripneumoniae, M. mycoides LC or M. capri alone were involved or isolated leading to unambiguous association between the aetiological agents and the observed pathology.

Other clinical signs such as mastitis, arthritis and keratitis which are commonly associated with M. mycoides LC infection (DaMassa et al. 1992, Rodriquez et al. 1995) were not observed in the present study, probably suggesting that the mycoplasma strains in the outbreaks were predominantly pneumotropic. It has recently been demonstrated that $M$. capripneumoniae which was previously considered to be a spe- cific goat pathogen can be isolated from cases of fibrinous pleuropneumonia in sheep with clinicopathological features that are indistinguishable from those of classical CCPP (Bölske et al. 1995). Such observations probably reflect an antigenic drift in $M$. capripneumoniae strains, some of which have developed virulent mechanisms for unconventional hosts such as sheep. This may also explain the variation in the pathological features associated with $M$. capripneumoniae as observed in this study. Furthermore, it has recently been demonstrated that genetic heterogeneity exists among $M$. $c a$ pripneumoniae strains isolated from east Africa including Tanzania (Petterson et al. 1998, Kokotovic et al. 2000, Msami et al. 1998), which may also probably explain the divergence in the observed pathological features.

Another striking observation in this study was the isolation of $M$. mycoides SC from a sequestrum from a goat that had died after antibiotic treatment. Although sequestration has been observed in caprine pleuropneumonia caused by M. capripneumoniae and M. mycoides SC (MacOwan 1976, MacOwan \& Minette 1976, Kaliner \& MacOwan 1976, Wesonga et al. 1998), this is the first report in which M. mycoides subsp. mycoides has been isolated from such lesions. This observation suggests the need for further investigations on the frequency of sequestration and its role in the carrier status of goats infected with $M$. mycoides SC. $M$. mycoides LC can also be isolated from the ear canals and ear mites of healthy carriers as well as clinically sick goats (Cottew \& Yeats 1982, DaMassa 1990, Gil et al. 1999). A further investigation on whether antibiotic treatment facilitates the development of sequestra in M. mycoides SC infected goats as is the case in cattle (Masiga et al. 1996) is worthwhile.

The isolation of $M$. capripneumoniae and $M$. mycoides SC in the Coast and Morogoro regions confirmed the occurrence of these myco- 
plasmas in the 2 regions for the first time. The fact that the outbreak of CCPP in Morogoro region was linked to goats that originated from Gairo division which borders Dodoma region leads to a suspicion that probably Dodoma is also a CCPP-affected region. Msami et al. (1998) reported the occurrence of CCPP in Tanzania for the first time and associated the outbreak of the disease in Dar es Salaam with goats originating from Singida region that borders Dodoma. Uncontrolled movements of animals from the affected areas are the major factor in the spread of CCPP (Thiaucourt \& Bölske 1996). Therefore, movements of infected goats from Dodoma or Singida regions by nomadic migrations or trade to Morogoro and Coast regions may have been responsible for the introduction of the disease in these regions. It is also possible that carrier animals from Dodoma and Singida destined for sale in Dar es Salaam city may have come into contact with uninfected animals on the way and transmitted the disease. The fact that within 2 years of emergency in the country CCPP has spread to about one quarter of the country, signifies the serious risk to which the goat population is exposed if further spread of the disease cannot be checked.

Treatment of CCPP-suspected goats with antibiotics at SUA farm may have been responsible for the low morbidity and mortality rates observed as it did in the Mkuranga herd. In the first outbreaks of CCPP in Arusha, Dar es Salaam, Kilimanjaro and Tanga regions the morbidity and mortality rates of $51.8 \%$ and 30 $71 \%$, respectively were recorded (Msami et al. 1998). Other workers have also reported that the morbidity and mortality due to CCPP in newly infected areas to be in the range of $50 \%$ 70\% and 60\%-70\%, respectively (Litamoi et al. 1990, Bölske et al. 1995, Nicholas 1999).

The recurrence of clinical cases among goats at SUA farm after antibiotic treatment needs further investigations because the carrier status in
CCPP-affected goats is still not well known (Thiaucourt \& Bölske 1996, Wesonga et al. 1998). Thus, it is not clear whether the relapse of the disease was due to reactivation of latent infections or was due to new infections. Both possibilities could have occurred because goats from different units in the farm and sometimes goats from outside the University farm share grazing areas. Poor response to antimicrobial therapy may have also resulted from poor quality drugs or inadvertent use by the farm personnel. Controlled clinical trials are required to ascertain the reasons for these observations. In contrast, recurrence of the clinical disease was not experienced in the Mkuranga herd after mass treatment with oxytetracycline. Msami et al. (1998) also reported that mass treatment with oxytetracycline curtailed further deaths in a CCPP-affected herd in Dar es Salaam region. In conclusion, this study confirmed the presence of $M$. capripneumoniae and $M$. mycoides $\mathrm{SC}$ infections in goats in the Coast and Morogoro regions of eastern Tanzania where the infections have not been reported before. CCPP, which was absent in the country until 2 years ago is spreading very fast, now encompassing about one quarter of the country including the major goat rearing regions. So far the disease has been confirmed by isolation of $M$. capripneumoniae in Arusha, Coast, Dar es Salaam, Kilimanjaro, Morogoro and Tanga regions and highly suspicious outbreaks have been reported in Dodoma, Iringa, Mtwara and Singida regions probably signifying an extensive distribution of the disease than actually documented. As yet, the origin of the disease in Tanzania has not been identified. Under the current situation when there is no specific policy for the control of the disease, it would appear that the disease will continue to spread unchecked and may extend to neighbouring countries in southern Africa. Therefore, concerted efforts are needed to control the disease in order to protect the goat 
population in the country and neighbouring countries. Studies are also required to verify the efficacy of antimicrobial therapy in CCPP in view on the conflicting reports on its effectiveness because, in the absence of effective vaccines, antimicrobial therapy remains to be the only means available for the farmers to minimise morbidity and mortality in their herds.

\section{Acknowledgements}

The technical assistance of Andrea Cosmas, Maulid Ndaki and Jonas Fitwangile (Sokoine University of Agriculture) and Lotte Clemmensen and Ulla Amtoft (Danish Veterinary Laboratory) is highly appreciated. We also thank Dr. H. M. Msami of the Animal Disease Research Institute, Dar es Salaam for providing information and CCPP-suspected specimens from Chalinze and Mkuranga. Dr. Göran Bölske of the National Veterinary Institute, Uppsala is thanked for confirming the identity of some of the mycoplasma isolates. The financial grant to the first author by the Danish International Development Agency is highly appreciated.

\section{References}

Bar-Moshe B, Rappaport E: Observations on Mycoplasma mycoides subsp. mycoides infection in Saanen goats. Isr. J. Med. Sci. 1981, 17, 537-539.

Bölske G: Respiratory mycoplasmoses in goats especially with regard to diagnosis of contagious caprine pleuropneumonia. Ph.D. thesis, Swedish University of Agricultural Sciences, Uppsala, 1995.

Bölske G, Engvall A, Renström LHM, Wierup M: Experimental infections in goats with Mycoplasma mycoides subspecies mycoides, LC type. Res. Vet. Sci. 1989, 46, 247-252.

Bölske G, Johansson K-E, Heinonen R, Panvuga PA, Twinamasiko E: Contagious caprine pleuropneumonia in Uganda and isolation of Mycoplasma capricolum subsp. capripneumoniae from goats and sheep. Vet. Rec. 1995, 137, 594.

Cottew GS, Yeats FR: Mycoplasmas and mites in the ears of clinically normal goats. Aust. Vet. J. 1982, 59, 77-81.

DaMassa AJ: The ear canal as a culture site for demonstration of mycoplasmas in clinically normal goats. Aust. Vet. J. 1990, 67, 267-269

DaMassa AJ, Wakenell PS, Brooks DL: Mycoplas- mas of goats and sheep. J. Vet. Diagn. Invest. 1992, 4, 101-113.

Gil MC, De Mendoza MH, Rey J, Alonso JM, Poveda $J B$, De Mendoza $J$ : Isolation of mycoplasmas from the external ear canal of goats affected with contagious agalactia. The Vet. J. 1999, 158, 152154.

Jones GE, Woods AR: Microbiological and serological studies on caprine pneumonias in Oman. Res. Vet. Sci. 1988, 44, 125-131.

Kaliner G, MacOwan KJ: The pathology of experimental and natural contagious caprine pleuropneumonia in Kenya. Zbl. Vet. Med. B. 1976, 23, 652-661.

Kokotovic B, Bölske G, Ahrens P, Johansson KE: Genomic variations of Mycoplasma capricolum subsp. capripneumoniae detected by amplified fragment length polymophism (AFLP) analysis. FEMS Microbiol. Letters. 2000, 184, 63-68.

Kusiluka LJM, Ojeniyi B, Friis NF, Kazwala RR, Kokotovic $B$ : Mycoplasmas isolated from the respiratory tract of cattle and goats in Tanzania. Acta vet. scand. 2000, 41, 000-000.

Lefèvre PC, Jones GE, Ojo MO: Pulmonary mycoplasmoses of small ruminants. Rev. sci. tech. Off. int. Epiz. 1987, 6, 759-799.

Litamoi JK, Wanyangu SW, Simam PK: Isolation of Mycoplasma biotype F38 from sheep in Kenya. Trop. Anim. Hlth. Prod. 1990, 22, 260-260.

MacOwan KJ: A mycoplasma from chronic caprine pleuropneumonia in Kenya. Trop. Anim. Hlth. Prod. 1976, 8, 28-36.

MacOwan KJ, Minette JE: A mycoplasma from acute contagious caprine pleuropneumonia in Kenya. Trop. Anim. Hlth. Prod. 1976, 8, 91-95.

MacOwan KJ, Minette JE: The role of mycoplasma strain F38 in contagious caprine pleuropneumonia in Kenya. Vet. Rec. 1977, 101, 380-381.

Masiga WN, Domenech J, Windsor RS: Manifestation and epidemiology of contagious bovine pleuropneumonia in Africa. Rev. sci. tech. Off. int. Epiz. 1996, 15, 1283-1308.

McMartin DA, MacOwan KJ, Minette JE: A century of classical contagious caprine pleuropneumonia: from original description to aetiology. $\mathrm{Br}$. Vet. J. 1980, 136, 507-515.

Msami HM: Pneumonias in goats in Tanzania with special regard to mycoplasma infections. Proc. $9^{\text {th }}$ Tanzania Vet. Assoc. Sci. Conf., Arusha, December 1991.

Msami HM, Kapaga AM, Bölske G, Kiramo RT, Mundogo J, Mbise A: Occurrence of contagious 
caprine pleuropneumonia in Tanzania. Tanzania Vet. J. 1998, 18, 285-297.

Nicholas $R$ : Contagious caprine pleuropneumonia. State Vet. J. 1999, 9, 11-13.

Nyange JFC, Mbise AN: Suspected contagious caprine pleuropneumonia and canine parvovirus enteritis in Northern Tanzania. Proc. $1^{\text {st }}$ Tanzania Vet. Assoc. Sci. Conf., Morogoro, 1983.

Ojo M: Caprine pneumonia IV. Pathogenicity of $M y$ coplasma mycoides subspecies capri and caprine strains of Mycoplasma mycoides subsp. mycoides for goats. J. Comp. Path. 1976, 86, 519-529.

Okoh AEJ, Ocholi RA: Diseases associated with $M y$ coplasma mycoides subspecies mycoides in sheep in Nigeria. Vet. Rec. 1986, 118, 212.

Pettersson B, Bölske G, Thiaucourt F, Uhlén M, Johansson KE: Molecular evolution of Mycoplasma capricolum subsp. capripneumoniae strains, based on polymophisms in the $16 \mathrm{~S}$ rRNA genes. J. Bacteriol. 1998, 180, 2350-2358.

Radwan AI, Al-Zeftawi NM, Al-Issa MA, Bekairi SA, Mukayel $A A$ : Mycoplasmas isolated from goats and sheep with pleuropneumonia in Saudi Arabia. Trop. Anim. Hlth. Prod. 1985, 17, 233-238.

Rodríguez JL, Poveda JB, Orös J, Herráez P, Sierra $M A$, Fenández A: High mortality of goats associated with the isolation of a strain of $\mathrm{Myco}-$ plasma mycoides subsp. mycoides (Large Colony Type). J. Vet. Med. B. 1995, 42, 587-593.

Rosendal $S$ : Ovine and caprine mycopasmas, In: Whitford HW, Rosenbusch RF, Lauermann LH (eds): Mycoplasmosis in Animals: Laboratory diagnosis. $1^{\text {st }}$ ed. Iowa State University Press, Ames, 1994.

Thiaucourt F, Bölske $G$ : Contagious caprine pleuropneumonia and other pulmonary mycoplasmoses of sheep and goats. Rev. sci. tech. Off. int. Epiz. 1996, 15, 1397-1414.

Thiaucourt F, Bölske G, Leneguersh B, Smith D, We- songa $H$ : Diagnosis and control of contagious caprine pleuropneumonia. Rev. sci. tech. Off. int. Epiz. 1996, 15, 1415-1429.

Wesonga H, Linderberg R, Litamoi JK, Bölske G: Late lesions of experimental contagious caprine pleuropneumonia caused by Mycoplasma capricolum ssp. capripneumoniae. J. Vet. Med. B. 1998, $45,105-114$.

\section{Sammendrag}

Påvisning af Mycoplasma capricolum subsp. capripneumoniae og Mycoplasma mycoides subsp. mycoides Small Colony type ved udbrud af caprin pleuropneumoni i det østlige Tanzania.

Et udbrud af caprin pleuropneumoni omfattende omkring 1200 geder i Coast og Morogoro regionerne i det østlige Tanzania er beskrevet. De fremherskende kliniske fund var alvolige respiratoriske problemer, feber, mukopurulent næsehuleudflåd og høj mortalitet $\mathrm{i}$ alle aldersgrupper hos både han- og hundyr. Morbiditeten og mortaliteten varierede fra henholdsvis $45 \%$ til $90 \%$ og $14 \%$ til $50 \%$. De dominerende patologiske forandringer var begrænset til thoracal hulen og bestod i hydrothorax og serofibrinøs pleuropneumoni. De histopatologiske forandringer bestod $i$ fibrinudsvedninger og cellulære migration til alveole lumina og septae samt til interlobulære septae og pleura. Mycoplasma capricolum subsp. capripneumoniae, Mycoplasma mycoides subsp. mycoides, Small Colony type Mycoplasma ovipneumoniae og Mycoplasma arginini, blev isoleret fra de undersøgte geder, og i eet tilfælde isoleredes Mycoplasma mycoides subsp. mycoides fra et sekvester. I dette arbejde beskrives for første gang et udbrud af caprin pleuropneumoni i Tanzania, hvor $M$. capripneumoniae og M. mycoides subsp. mycoides kunne isoleres simultant.

(Received February 14, 2000; accepted June 6, 2000).

Reprints may be obtained from: L.J.M. Kusiluka, Department of Veterinary Medicine and Public Health, Sokoine University of Agriculture, P.O. Box 3021, Morogoro, Tanzania. E-mail: kusiluka@suanet.ac.tz, tel: +255232 604542, fax: +255232604647. 